\title{
Incised-Punctated Utility Ware Sherds from Lake Sam Rayburn Ancestral Caddo Sites
}

Timothy K. Perttula

Heritage Research Center, Stephen F. Austin State University

Mark Walters

Heritage Research Center, Stephen F. Austin State University

Follow this and additional works at: https://scholarworks.sfasu.edu/ita

Part of the American Material Culture Commons, Archaeological Anthropology Commons, Environmental Studies Commons, Other American Studies Commons, Other Arts and Humanities Commons, Other History of Art, Architecture, and Archaeology Commons, and the United States History Commons

Tell us how this article helped you.

This Article is brought to you for free and open access by the Center for Regional Heritage Research at SFA ScholarWorks. It has been accepted for inclusion in Index of Texas Archaeology: Open Access Gray Literature from the Lone Star State by an authorized editor of SFA ScholarWorks. For more information, please contact cdsscholarworks@sfasu.edu. 
Incised-Punctated Utility Ware Sherds from Lake Sam Rayburn Ancestral Caddo Sites

\section{Creative Commons License}

\section{(c) (1) (9)}

This work is licensed under a Creative Commons Attribution-NonCommercial 4.0 International License 


\title{
Incised-Punctated Utility Ware Sherds from Lake Sam Rayburn Ancestral Caddo Sites
}

\author{
Timothy K. Perttula and Mark Walters
}

\section{INTRODUCTION}

One of the more distinctive of the decorative methods represented in the ancestral Caddo ceramic assemblages from Lake Sam Rayburn sites is sherds and vessels with incised-punctated decorative elements. This diversity in the range and character of sherds and vessels with incised-punctated decorative elements is also the case in ancestral Caddo sites on the Sabine River and tributaries in the Toledo Bend Reservoir area of East Texas and Northwest Louisiana (Perttula 2015; Perttula and Walters 2015).

Jelks (1965:119-122 and Figure 61a-g) included the incised-punctated vessels and sherds from the Lake Sam Rayburn sites in a newly defined type: Pineland Punctated-Incised (Figure 1). Pineland Punctated-Incised is a grog and/or bone-tempered utility ware, and occurs primarily as beaker-shaped jars as well as ollas and deep bowls. The vessels have concentric, triangular, rectangular, and curvilinear incised zones on the rim filled with tool punctations (Figure 1). Ollas and bowls have design elements on the vessel bodies (see Jelks 1965:Figure 61d, g).

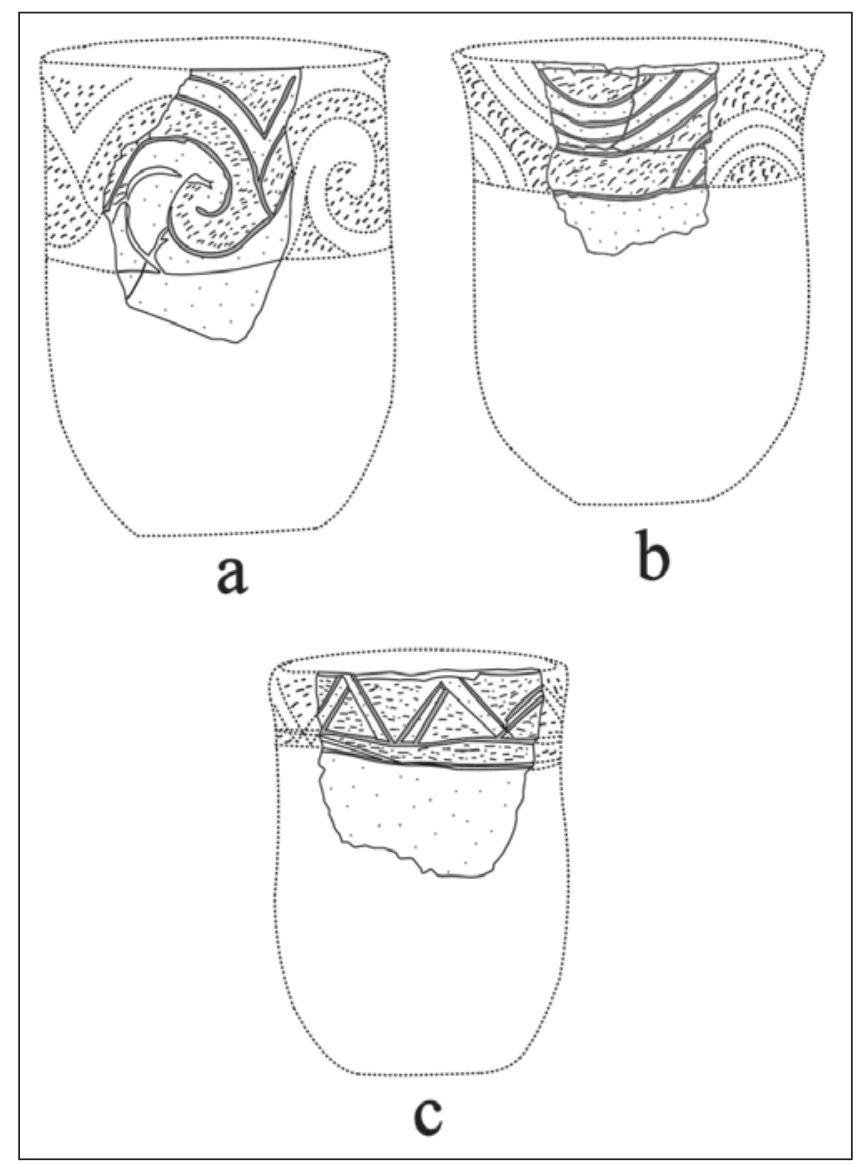

Figure 1. Pineland Punctated-Incised vessels and decorative elements (after Jelks 1965:Figure 61). 
At Lake Sam Rayburn sites, Pineland Punctated-Incised sherds and vessels occur in both Middle Caddo (ca. A.D. 1200-1400/1450) and Late Caddo (ca. A.D. 1400/1450-1680) contexts. Based on the analyses discussed below, incised-punctated utility wares are most abundant in later Middle Caddo period components estimated to date from ca. A.D. 1300-1400/1450, and least common in post-A.D. 1400/1450 Late Caddo period components.

\section{Utility Ware Assemblages}

Vessels and sherds with incised-punctated decorative motifs and elements are a consistent part of the assemblage of utility wares in the Lake Sam Rayburn sites, along with vessels and sherds with brushed, incised, and punctated decorative elements (Table 1; see Jelks 1965). In Lake Sam Rayburn assemblages with more than 169 decorated utility ware sherds, sherds with incised-punctated decorative elements comprise between 3.5-13.2 percent of the utility ware sherd assemblages. The sites with the highest proportion of incised-punctated sherds in the utility ware assemblages are Blount (13.2 percent) and Sawmill (10.0 percent).

Table 1. Utility ware sherds from Lake Sam Rayburn sites with incised-punctated ceramics as classified by Jelks (1965:119-132).

\begin{tabular}{lllllll}
\hline Sites & PPI & BB & I & P & I-P-B & N \\
\hline Sawmill & 300 & 955 & 939 & 689 & 101 & 2984 \\
Walter Bell & 203 & 2112 & 1740 & 166 & 71 & 4292 \\
Etoile & 176 & 1174 & 316 & 390 & 70 & 2126 \\
Blount & 121 & 332 & 255 & 208 & 4 & 920 \\
Wylie Price & 73 & 570 & 119 & 87 & 82 & 931 \\
McElroy & 54 & 325 & 497 & 140 & 10 & 1126 \\
Print Bell & 40 & 53 & 337 & 46 & 9 & 485 \\
Brink Powell & 6 & 104 & 43 & 7 & 9 & 169 \\
Sowell & 3 & 11 & 29 & 13 & 1 & 57 \\
Runnells \#1 & 1 & - & 6 & - & - & 7 \\
\hline Totals & 977 & 5636 & 4281 & 1746 & 357 & 13097 \\
\hline
\end{tabular}

PPI=Pineland Punctated-Incised; $\mathrm{BB}=$ Broaddus Brushed; $\mathrm{I}=$ miscellaneous incised; $\mathrm{P}=$ miscellaneous punctated; I-P-B: sherds with "various combinations of incising, punctating, and brushing... as well as a few unusual appliqued and corrugated sherds" (Jelks 1965:132).

Middlebrook (1994:Figure 4) has used differences in the relative proportion of brushed versus incised-punctated sherds in local assemblages to differentiate sites by age and affiliation: early (ca. A.D. 1200-1400/1450) versus late (ca. A.D. 1400/1450-1680) Angelina phase. In these groupings, incised-punctated sherds are more common in the early Angelina phase sites relative to brushed sherds, and the converse is the case in late Angelina phase sites (Middlebrook 1994:29). How the style of these incised-punctated vessels and vessel sherds may have changed through time is of particular relevance in this study of the incised-punctated sherds from Lake Sam Rayburn sites, as well as whether it is possible to identify distinct varieties of incised-punctated sherds that may have chronological significance in these Middle and Late Caddo period sites.

\section{Lake Sam Rayburn Sites}

The incised-punctated sherds from the Lake Sam Rayburn sites are in the collections of the Texas Archeological Research Laboratory at The University of Texas at Austin (TARL); based on examined sherd samples, there are incised-punctated sherds currently unaccounted for in the assemblages available for study. In addition to sorting the incised-punctated sherds by temper and sherd type (i.e., rim and body) from nine 
different site sherd assemblages, of particular concern was the identification of distinctive motifs and decorative elements on these vessel sherds in each site assemblage. The 21 vessels from Lake Sam Rayburn sites were also documented, and there is one incised-punctated-brushed jar and an incised-punctated carinated bowl from the Walter Bell site (Perttula and Walters 2016:Figures 4-5), and a shell-tempered incised-punctated jar from the Wylie Price site (Perttula and Walters 2016:Figure 9).

In the case of the few Etoile site sherds with incised-punctated decorative elements (Table 2), these body sherds have either parallel incised lines with punctated rows between sets of lines (Figure $2 \mathrm{a}-\mathrm{b}$ ), or straight lines with an adjacent tool punctated row. One body sherd has parallel and diagonal incised lines with a row of linear tool punctates pushed through the incised lines (Figure 2c)

Table 2. Incised-Punctated sherds from the Etoile site (41NA11).

\begin{tabular}{llll}
\hline Decorative Method/Element & Rim & Body & $\mathrm{N}$ \\
\hline $\begin{array}{l}\text { Incised-Punctated } \\
\text { parallel lines and single fingernail punctate } \\
\text { parallel lines with tool punctated rows on } \\
\text { either side of lines } \\
\text { parallel lines with tool punctated row between lines } \\
\text { parallel and diagonal lines and row of linear } \\
\quad \text { tool punctates overlying incised lines }\end{array}$ & - & 1 & 1 \\
straight line and adjacent tool punctated zone & - & 1 & 1 \\
\hline Totals & - & 1 & 1 \\
\hline
\end{tabular}

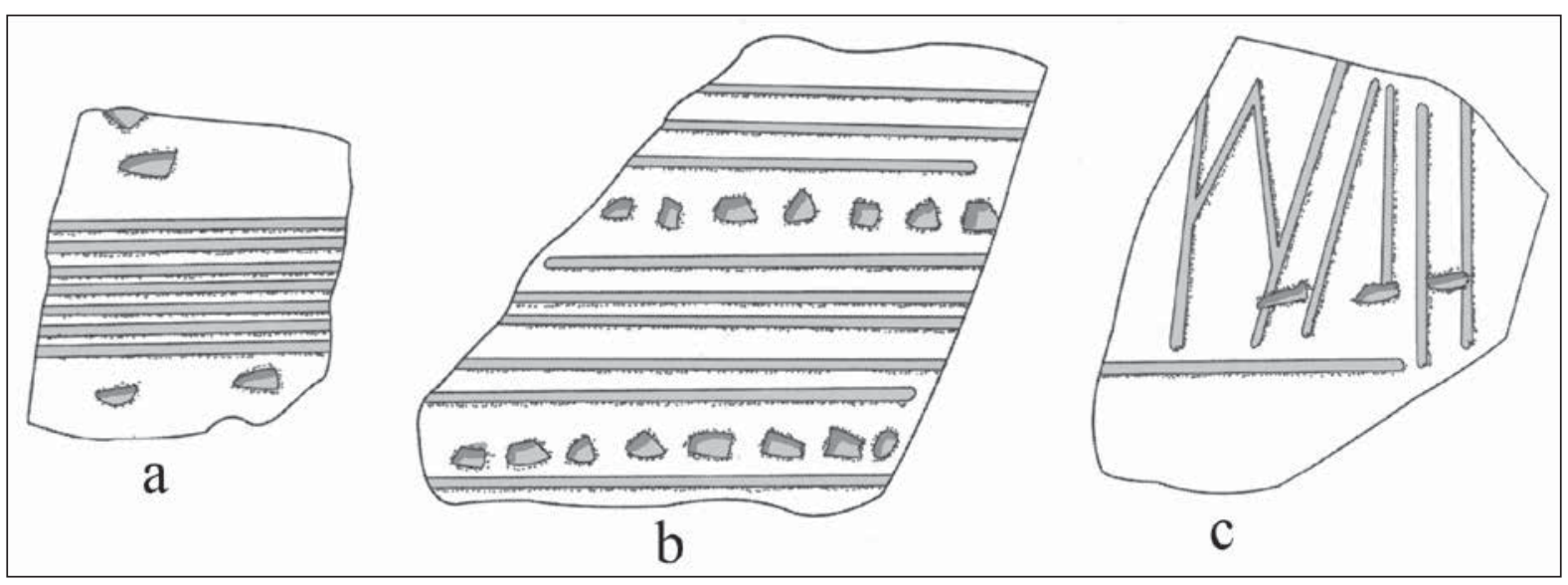

Figure 2. Selected incised-punctated body sherds from the Etoile site.

Most of the incised-punctated rim sherds at the Brink Powell site (41SB8) have diagonal opposed incised triangles filled with tool punctations (Table 3 and Figure 3a); these may be from Maydelle Incised vessels (see Suhm and Jelks 1962), although Jelks (1965) subsumes this decorative motif within the Pineland Punctated-Incised type; below we classify such sherds as Pineland Punctated-Incised, var. Powell. The other incised-punctated rim sherd has horizontal incised zones or panels filled with punctations (Figure $3 b$ ). 
Table 3. Incised-Punctated sherds from the Brink Powell Site (41SB8).

\begin{tabular}{llll}
\hline Decorative Method/Element & Rim & Body & N \\
\hline $\begin{array}{l}\text { Incised-Punctated } \\
\text { horizontal incised panels filled with tool punctates }\end{array}$ & 1 & - & 1 \\
incised triangle el. filled with tool punctates & 5 & - & 5 \\
\hline Totals & 6 & - & 6 \\
\hline
\end{tabular}

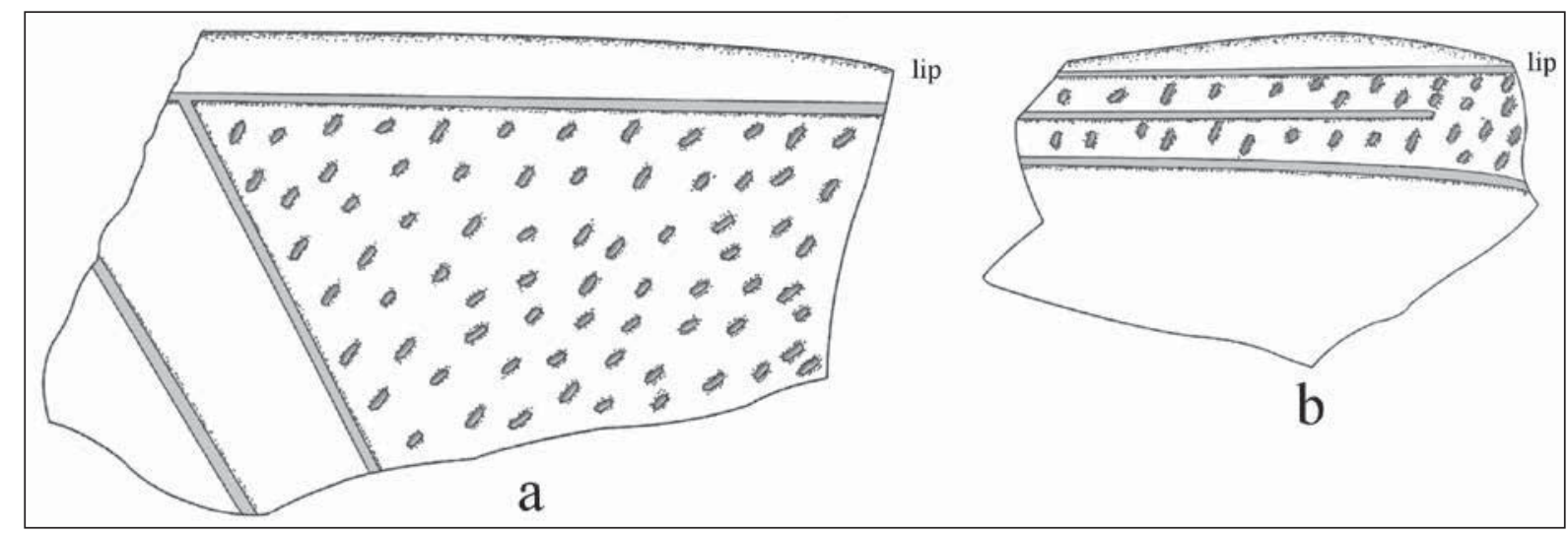

Figure 3. Selected incised-punctated decorative elements on sherds from the Brink Powell site.

The sample of incised-punctated rim and body sherds in the TARL collection from the Print Bell site includes 12 rims and 38 body sherds (Table 4). A number of the rims have horizontal incised zones filled with rows of linear tool punctations or have a horizontal incised line and zone with upper and lower punctated rows (Figure $4 \mathrm{c}-\mathrm{d}$ ); these are designated below as Pineland Punctated-Incised, var. Print. Another rim has two rows of tool punctations above a single horizontal line and a series of diagonal incised lines below the horizontal line (Figure 4e). Several others have a diagonal incised zone filled with tool punctates or diagonal incised panels filled with circular punctates (Figure $4 \mathrm{a}-\mathrm{b}$ ).

Table 4. Incised-punctated sherds from the Print Bell site (41SB36).

\begin{tabular}{|c|c|c|c|}
\hline Decorative Method/Element & Rim & Body & $\mathrm{N}$ \\
\hline \multicolumn{4}{|l|}{ Incised-Punctated } \\
\hline circular incised zone filled with tool punctates & - & 1 & 1 \\
\hline curvilinear incised zone filled with circular punctates & - & 1 & 1 \\
\hline diagonal incised zone filled with tool punctates & 1 & - & 1 \\
\hline diagonal incised panels filled with circular punctates & 1 & - & 1 \\
\hline diagonal incised lines and vertical linear tool punctates & - & 1 & 1 \\
\hline horizontal incised zones filled with circular punctates & - & 3 & 3 \\
\hline $\begin{array}{l}\text { horizontal incised zone filled with rows of } \\
\text { linear tool punctations }\end{array}$ & 2 & - & 2 \\
\hline $\begin{array}{l}\text { horizontal incised line and zone with upper and } \\
\text { lower punctated rows }\end{array}$ & 1 & - & 1 \\
\hline $\begin{array}{l}\text { horizontal lines above triangular incised zone } \\
\text { filled with tool punctates }\end{array}$ & - & 1 & 1 \\
\hline
\end{tabular}


Table 4. Incised-punctated sherds from the Print Bell site (41SB36), cont.

\begin{tabular}{|c|c|c|c|}
\hline Decorative Method/Element & $\operatorname{Rim}$ & Body & $\mathrm{N}$ \\
\hline horizontal and diagonal lines above row of tool punctates & - & 1 & 1 \\
\hline horizontal punctated rows above horizontal line & 1 & - & 1 \\
\hline $\begin{array}{l}\text { horizontal punctated rows above horizontal and } \\
\text { diagonal incised lines }\end{array}$ & 1 & - & 1 \\
\hline $\begin{array}{l}\text { parallel incised lines with tool punctated rows } \\
\text { between lines }\end{array}$ & - & 4 & 4 \\
\hline $\begin{array}{l}\text { incised chevrons and incised triangles filled } \\
\text { with tool punctates }\end{array}$ & 1 & - & 1 \\
\hline incised triangles filled with tool punctates & - & 4 & 4 \\
\hline $\begin{array}{l}\text { triangular and curvilinear incised zones filled } \\
\text { with tool punctates }\end{array}$ & 1 & - & 1 \\
\hline $\begin{array}{l}\text { semi-circular incised zone filled with circular } \\
\text { punctations }\end{array}$ & 1 & - & 1 \\
\hline $\begin{array}{l}\text { semi-circular incised zone filled with tool } \\
\text { punctates }\end{array}$ & 2 & - & 2 \\
\hline $\begin{array}{l}\text { semi-circular incised zones and adjacent row } \\
\text { of tool punctates }\end{array}$ & - & 1 & 1 \\
\hline $\begin{array}{l}\text { straight incised line and adjacent circular } \\
\text { punctated zone }\end{array}$ & - & 5 & 5 \\
\hline $\begin{array}{l}\text { straight incised line and adjacent tool punctated } \\
\text { zone }\end{array}$ & - & 12 & 12 \\
\hline $\begin{array}{l}\text { straight incised line and adjacent tool punctated } \\
\text { row }\end{array}$ & - & 3 & 3 \\
\hline $\begin{array}{l}\text { straight incised line and adjacent triangular } \\
\text { tool punctated zone }\end{array}$ & - & 1 & 1 \\
\hline Totals & 12 & 38 & 50 \\
\hline
\end{tabular}

Other incised-punctated rims in the Print Bell site utility wares have triangle elements filled with tool punctations (see Figure 4f) or triangular and curvilinear incised zones filled with tool punctations (see Figure $4 \mathrm{~g}$ ). Several of the rims have semi-circular incised zones filled with punctates (see Figure $4 \mathrm{~h}-\mathrm{i}$ ); these are identified below as Pineland Punctated-Incised, var. Bell.

Body sherds from the Print Bell site with incised-punctated decorative elements have sets of parallel lines or parallel incised panels with tool or circular punctations between the incised lines (Figure $5 \mathrm{~d}-\mathrm{e}$ ). Others have horizontal incised lines and a tool punctate-filled triangle element (Figure 5c), incised triangles filled with punctations, or horizontal and diagonal incised lines above a row of tool punctations (Figure $5 \mathrm{~b}$ ). One body sherd has a series of diagonal incised lines with vertically-oriented linear tool punctations (Figure 5a).

Including both rim and body sherds, the principal incised-punctated decorative element at the Walter Bell site is incised triangles (formed by opposed sets of diagonal incised lines) filled with punctations (Table 5 and Figure 6b, g). Related to this are sherds with diagonal lines or panels filled with punctations (Figure 6a). 


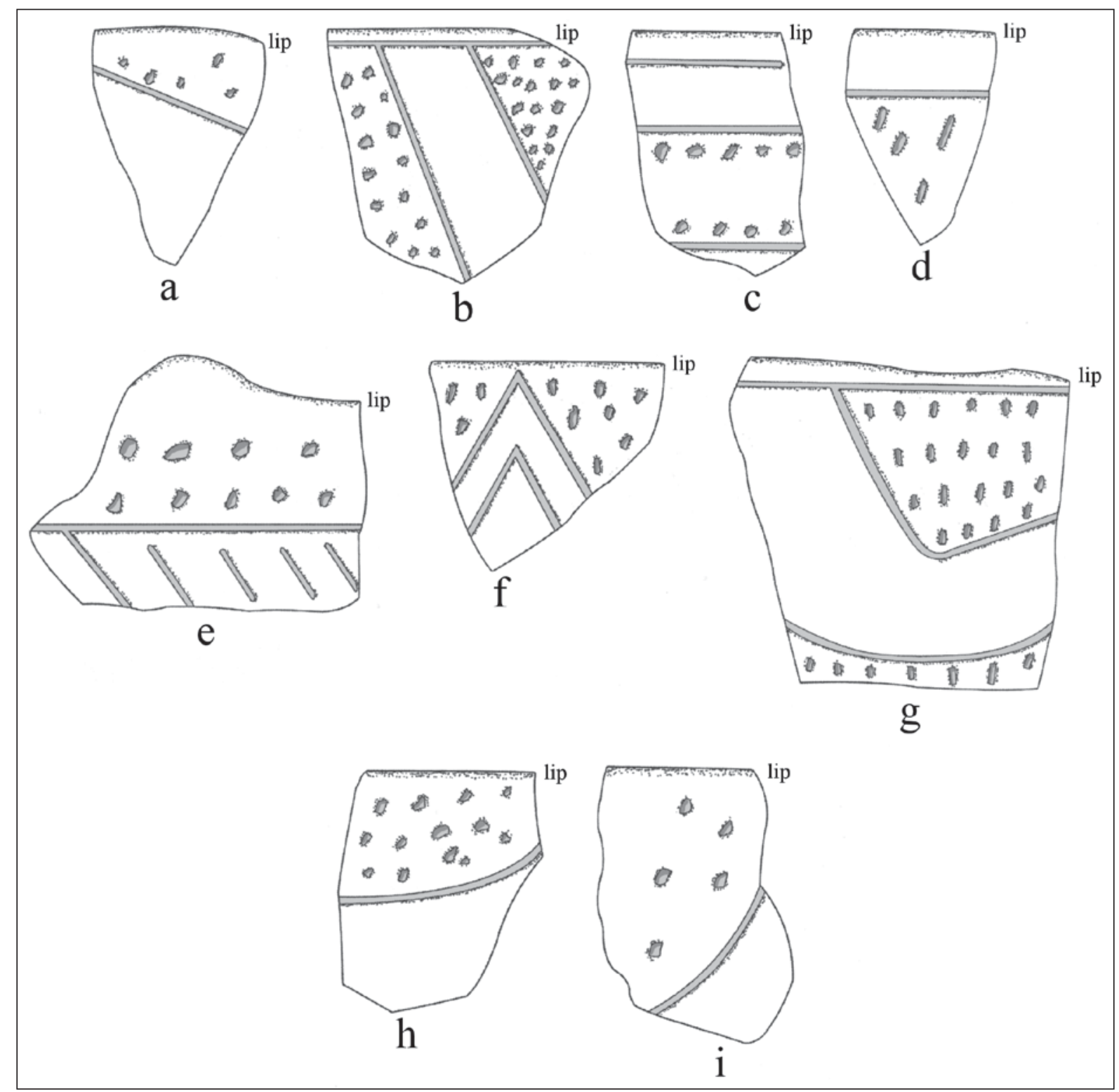

Figure 4. Selected incised-punctated rim sherds from the Print Bell site.

Table 5. Incised-punctated sherds from the Walter Bell site (41SB50). 
Table 5. Incised-punctated sherds from the Walter Bell site (41SB50), cont.

\begin{tabular}{llll}
\hline Decorative Method/Element & Rim & Body & N \\
\hline parallel incised panels filled with tool punctates & - & 1 & 1 \\
parallel lines and adjacent tool punctated zone & - & 6 & 6 \\
parallel lines and adjacent tool punctated row & - & 1 & 2 \\
parallel lines with row of tool punctates over lines & - & 2 & 2 \\
$\begin{array}{l}\text { rectilinear panel filled with tool punctates and } \\
\text { parallel row of tool punctates }\end{array}$ & - & 2 & 2 \\
straight line and adjacent tool punctated zone & & 9 & 1 \\
triangle filled with tool punctates & - & 1 & 1 \\
triangle filled with tool punctates, and horizontal \\
row of punctates above horizontal lines
\end{tabular}

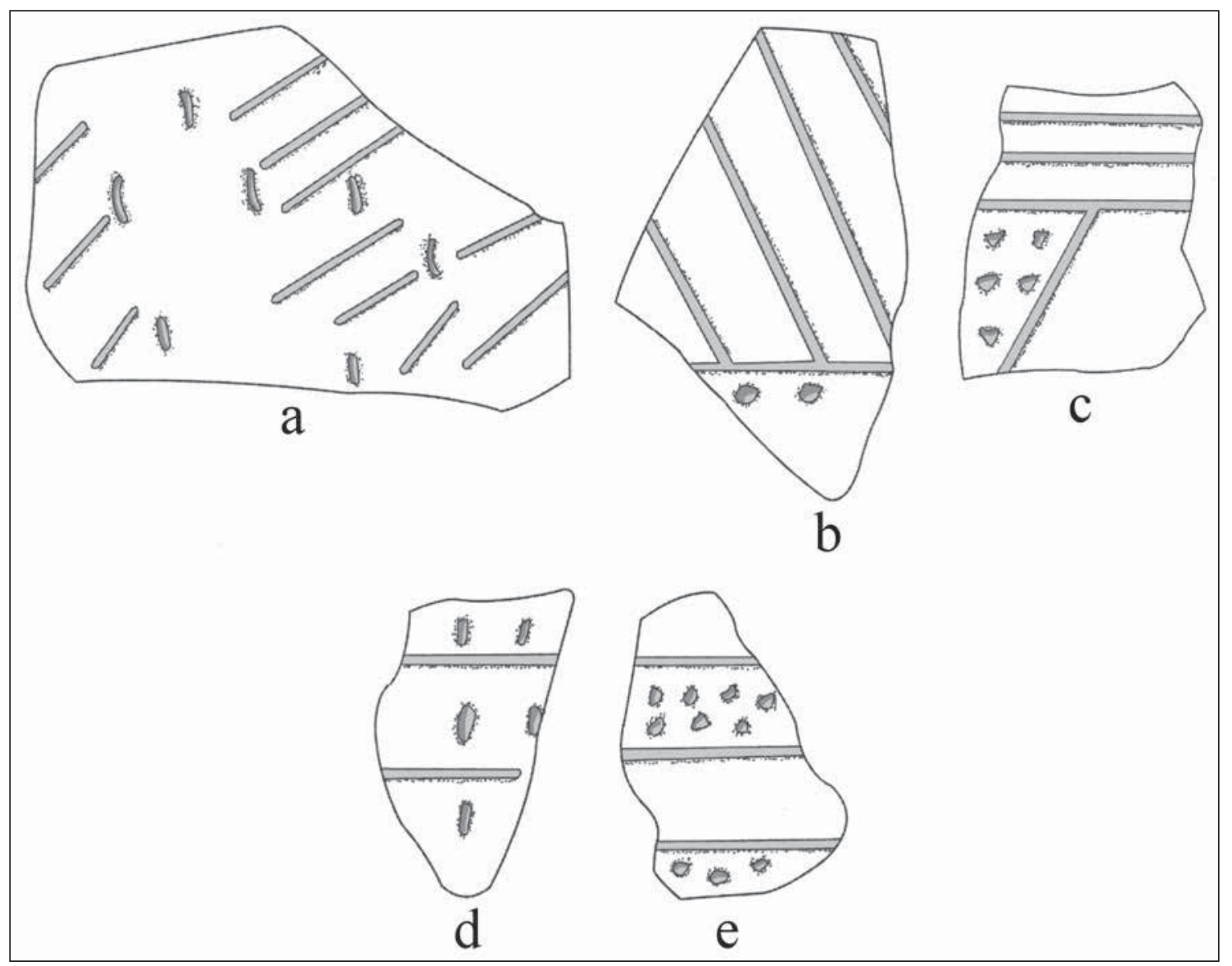

Figure 5. Selected incised-punctated body sherds from the Print Bell site. 


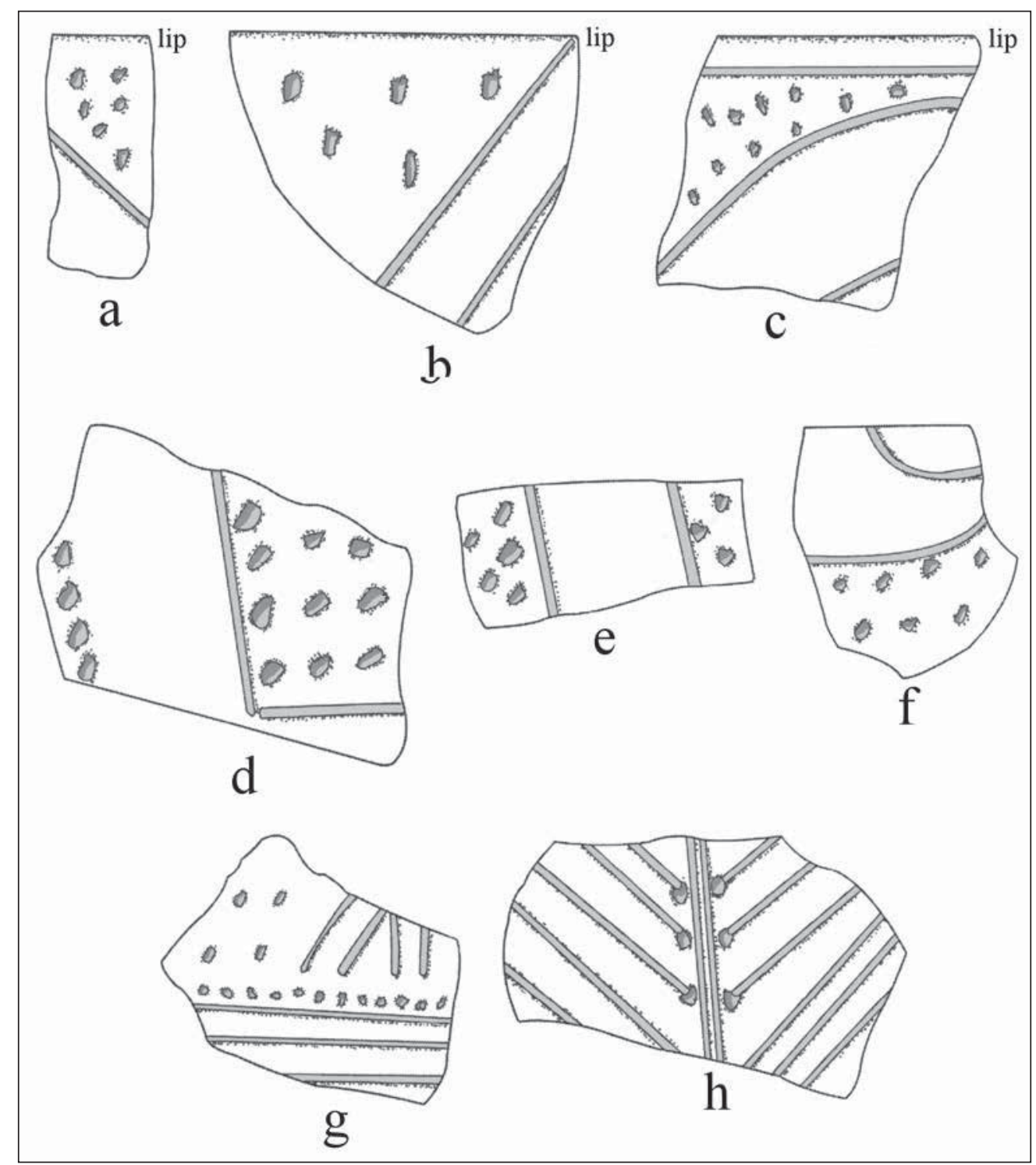

Figure 6. Selected incised-punctated sherds from the Walter Bell site: a-c, rim sherds; $\mathrm{d}-\mathrm{h}$, body sherds.

Other rims have a curvilinear zone filled with tool punctates (see Figure 6c), or horizontal rows of punctations below a horizontal line beneath the vessel lip. The last rim has a row of tool punctations below the vessel lip, and one diagonal incised line on the rim itself.

Four lower rim-body sherds from jars have horizontal incised lines on the rim and multiple tool punctated rows on the vessel body. In addition to the body sherds with incised triangle elements filled with punctations, there are several that have parallel incised lines and an adjacent tool punctated zone (see Table 5). One has parallel incised panels filled with tool punctations (see Figure 6e), and two others have rectilinear incised panels filled with tool punctates and a related parallel row of tool punctates (see Figure 6d). One body sherd has a curvilinear incised zone filled with small tool punctations (see Figure 6f). 
One of the incised-punctated body sherds from the Walter Bell site may be from a Pease Brushed-Incised jar. It has vertical and diagonal opposed incised lines and vertical tool punctated rows paralleling a vertical incised line (see Figure 6h).

The few incised-punctated rim and body sherds from the Roger Sowell site are from jars. The one rim has an incised triangle element, defined by opposed diagonal incised lines, that is filled with tool punctations (Table 6).

Table 6. Incised-Punctated sherds from the Roger Sowell site (41SA69).

\begin{tabular}{llll}
\hline Decorative Method/Element & Rim & Body & $\mathrm{N}$ \\
\hline $\begin{array}{l}\text { Incised-Punctated } \\
\text { diagonal incised lines and triangle el. filled } \\
\text { with tool punctates }\end{array}$ & 1 & - & 1 \\
straight incised line and adjacent tool punctated zone & - & 1 & 1 \\
\hline
\end{tabular}

A lower rim sherd from the E. E. Runnells No. 1 site (41SA87) from a grog-tempered jar has a series of closely-spaced horizontal incised lines above a single row of diagonal tool punctations (Figure 7a).

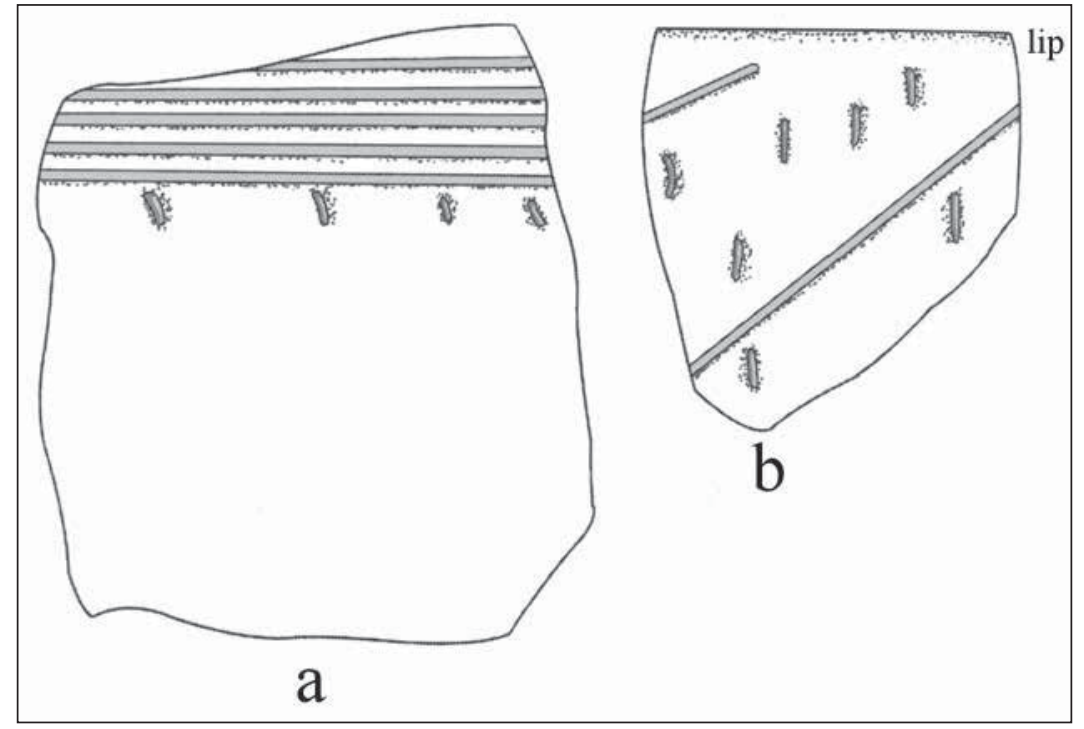

Figure 7. Incised-punctated sherd from the E. E. Runnells No. 1 site.

The Sawmill site incised-punctated rim sherds have several with diagonal lines or diagonal panels filled with punctations (Figure 8b-c and Table 7) as well as another with a curvilinear incised zone filled with circular punctates. One large rim (Figure 8a) from the site has semi-circular and curvilinear lines and zones filled with tool punctates, and there is a rim with a single horizontal line above a row of large circular punctates (Figure 8d). 
Table 7. Incised-punctated sherds from the Sawmill site (41SA89).

\begin{tabular}{|c|c|c|c|}
\hline Decorative Method/Element & Rim & Body & $\mathrm{N}$ \\
\hline \multicolumn{4}{|l|}{ Incised-Punctated } \\
\hline $\begin{array}{l}\text { curvilinear line and adjacent curvilinear zones } \\
\text { filled with circular punctates }\end{array}$ & - & 3 & 3 \\
\hline curvilinear line and adjacent tool punctated zone & - & 1 & 1 \\
\hline $\begin{array}{l}\text { curvilinear incised zone filled with circular } \\
\text { punctates }\end{array}$ & 1 & 1 & 2 \\
\hline diagonal line and circular punctated zone & 1 & - & 1 \\
\hline diagonal panel filled with circular punctates & 1 & - & 1 \\
\hline $\begin{array}{l}\text { diagonal opposed lines and semi-circular lines } \\
\text { with zone filled with circular punctates }\end{array}$ & 1 & - & 1 \\
\hline horizontal line above row of circular punctates & 1 & - & 1 \\
\hline $\begin{array}{l}\text { horizontal lines with fingernail punctated } \\
\text { rows between lines* }\end{array}$ & 1 & - & 1 \\
\hline $\begin{array}{l}\text { horizontal and cross-hatched lines above rows } \\
\text { of tool punctates [on body] }\end{array}$ & - & 1 & 1 \\
\hline $\begin{array}{l}\text { parallel lines and adjacent circular punctated } \\
\text { zone }\end{array}$ & - & 1 & 1 \\
\hline $\begin{array}{l}\text { semi-circular and curvilinear lines and zones } \\
\text { filled with tool punctates }\end{array}$ & 1 & - & 1 \\
\hline straight line and adjacent circular punctated zone & - & 1 & 1 \\
\hline $\begin{array}{l}\text { straight line and adjacent fingernail punctated } \\
\text { zone }\end{array}$ & - & 2 & 2 \\
\hline $\begin{array}{l}\text { straight line and tool punctated zones on either } \\
\text { side of the incised line }\end{array}$ & - & 1 & 1 \\
\hline triangular el. filled with circular punctates & - & 1 & 1 \\
\hline triangles filled with fingernail punctates & - & 1 & 1 \\
\hline vertical lines above row of linear tool punctates & - & 1 & 1 \\
\hline Totals & 7 & 14 & 21 \\
\hline
\end{tabular}

*Weches Fingernail Impressed, var. Weches

One of the incised-punctated rim sherds from the Sawmill site is from a Weches Fingernail Impressed, var. Weches jar (see Figure 8g), which suggests use of the site prior to ca. A.D. 1300. This sherd has crescent-shaped fingernail punctations that are bounded by a series of horizontal incised lines (Stokes and Woodring 1981:181).

Distinctive incised-punctated body sherds have triangular elements filled with small circular punctates (see Figure 8e) or have curvilinear line and adjacent curvilinear zones filled with circular punctates. One lower rim-body sherd has horizontal and cross-hatched incised lines on the rim and rows of large tool punctations on the vessel body (see Figure 8f). 


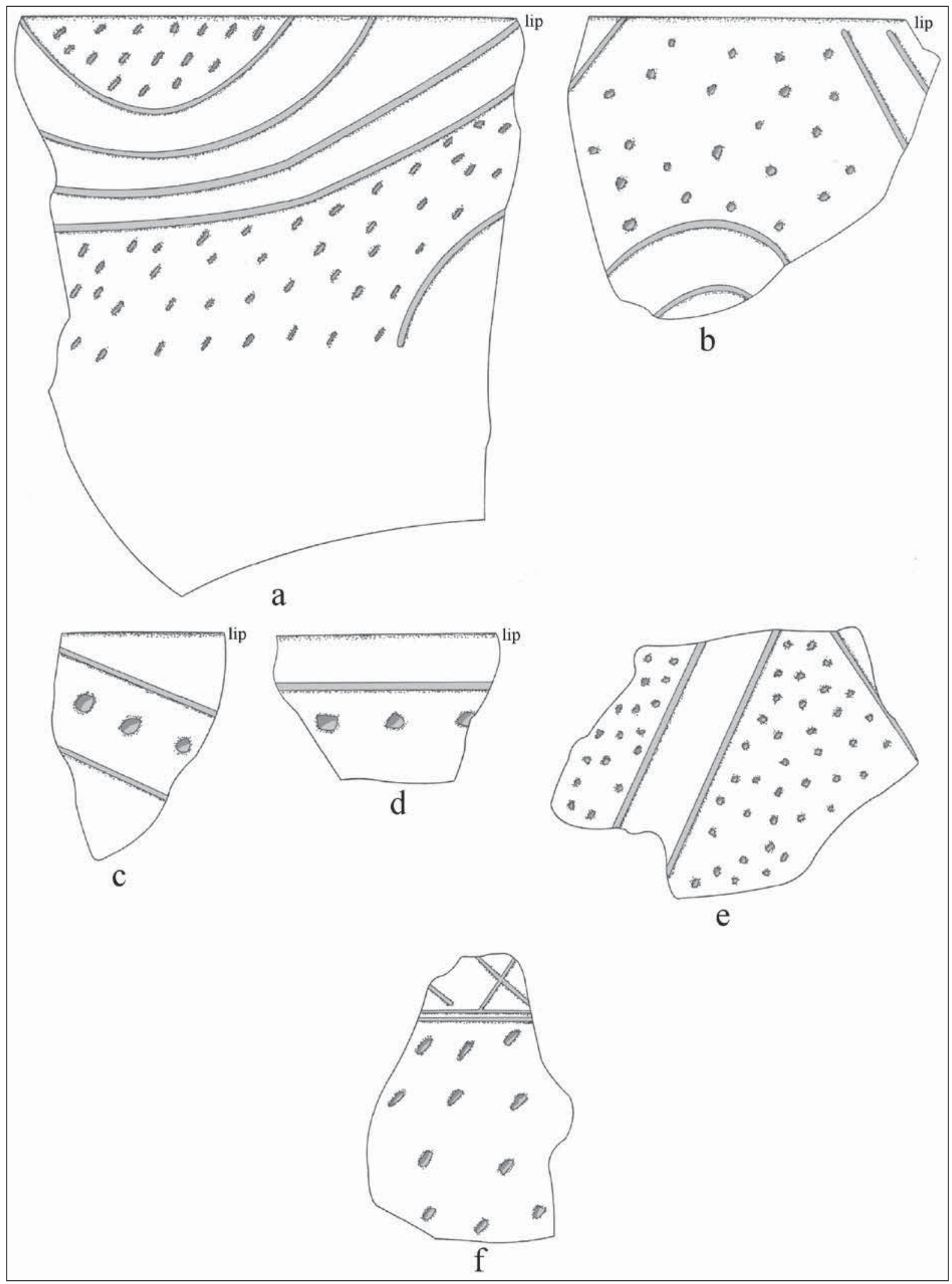

Figure 8. Selected incised-punctated sherds from the Sawmill site: a-d, g, rim sherds; e-f, body sherds. 
There are three incised-punctated body sherds in the TARL collections from the Wylie Price site (Table 8). These include one with a curvilinear incised panel filled with linear tool punctates (Figure 9a) and another with horizontal and vertical incised zones filled with circular punctates (Figure 9b).

Table 8. Incised-punctated sherds from the Wylie Price site (41SA94).

\begin{tabular}{|c|c|c|c|}
\hline Decorative Method/Element & Rim & Body & $\mathrm{N}$ \\
\hline $\begin{array}{l}\text { Incised-Punctated } \\
\text { curvilinear incised panel filled with linear tool } \\
\text { punctates }\end{array}$ & - & 1 & 1 \\
\hline $\begin{array}{l}\text { horizontal and vertical incised zones filled with } \\
\text { circular punctates }\end{array}$ & - & 1 & 1 \\
\hline $\begin{array}{l}\text { straight incised line and adjacent tool punctated } \\
\text { zone }\end{array}$ & - & 1 & 1 \\
\hline Totals & - & 3 & 3 \\
\hline
\end{tabular}

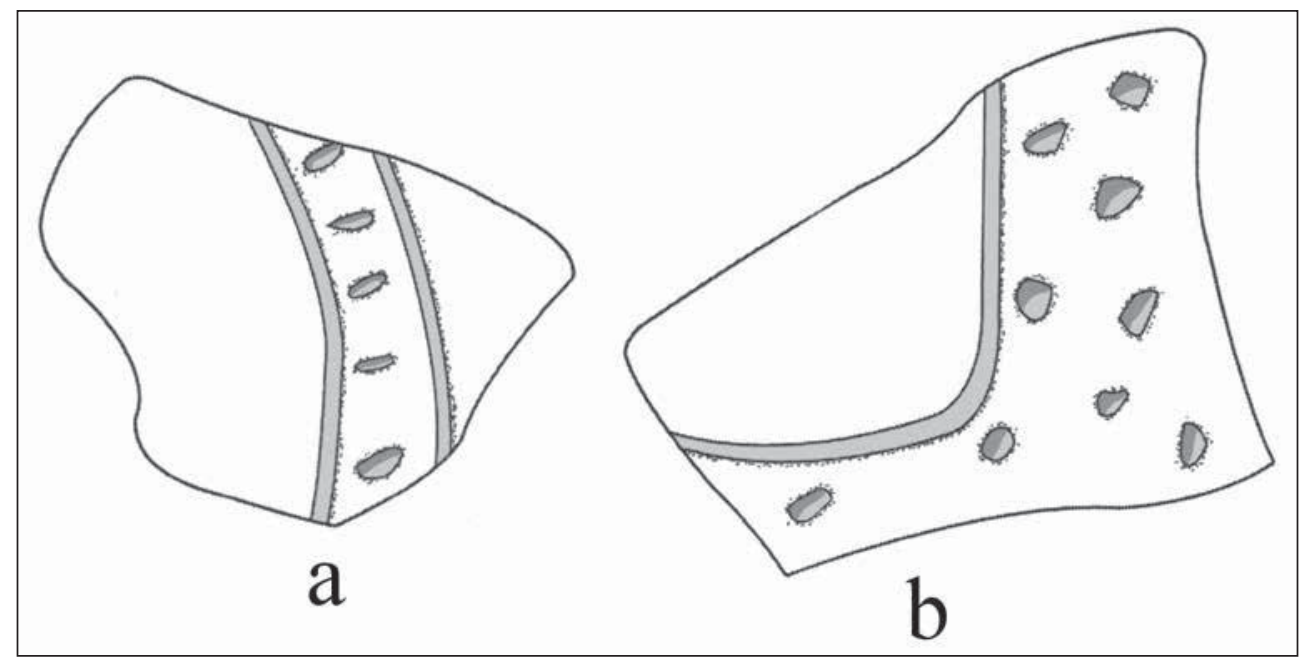

Figure 9. Selected incised-punctated body sherds from the Wylie Price site.

The largest sample of incised-punctated sherds in the Lake Sam Rayburn collections at TARL is from the Blount site: the assemblage includes 24 rim sherds and 100 body sherds (Table 9). The largest number of rim sherds have incised triangles filled with punctations (Figure 10a-c), and there are also several rims with either circular or curvilinear incised zones, sometimes in association with semi-circular zones, filled with punctations (Figure 10d-g).

Table 9. Incised-punctated sherds from the Blount site (41SA123).

\begin{tabular}{lccc}
\hline Decorative Method/Element & Rim & Body & N \\
\hline $\begin{array}{l}\text { Incised-Punctated } \\
\text { circular incised line and adjacent rows of tool } \\
\text { punctates and horizontal and vertical punctated rows } \\
\begin{array}{l}\text { circular incised zone filled with tool punctates } \\
\text { inter }\end{array}\end{array}$ & 1 & - & 1 \\
& - & 3 & 3
\end{tabular}


Table 9. Incised-punctated sherds from the Blount site (41SA123), cont.

\begin{tabular}{|c|c|c|c|}
\hline Decorative Method/Element & $\operatorname{Rim}$ & Body & $\mathrm{N}$ \\
\hline $\begin{array}{l}\text { curvilinear incised zones filled with either linear } \\
\text { punctates or diagonal hatched lines }\end{array}$ & - & 1 & 1 \\
\hline curvilinear incised zone filled with tool punctates & 1 & 4 & 5 \\
\hline curvilinear line and adjacent circular punctated zone & - & 3 & 3 \\
\hline curvilinear line and adjacent tool punctated zone & - & 6 & 6 \\
\hline $\begin{array}{l}\text { curvilinear incised line and tool punctated zone } \\
\text { on either side of the line }\end{array}$ & - & 1 & 1 \\
\hline curvilinear and semi-circular zones filled with tool punctates & 2 & - & 2 \\
\hline $\begin{array}{l}\text { curvilinear and semi-circular zones filled with } \\
\text { tool punctates and incised triangle el. }\end{array}$ & - & 1 & 1 \\
\hline diagonal incised panels filled with circular punctates & 2 & - & 2 \\
\hline $\begin{array}{l}\text { diagonal incised lines and horizontal and } \\
\text { diagonal rows of linear punctates }\end{array}$ & - & 1 & 1 \\
\hline diagonal and vertical lines with tool punctates & - & 1 & 1 \\
\hline diagonal opposed lines and adjacent rows of linear tool punctates & - & 1 & 1 \\
\hline horizontal incised zone filled with circular punctated rows & 2 & - & 2 \\
\hline $\begin{array}{l}\text { horizontal line and semi-circular zone and } \\
\text { adjacent tool punctated zones }\end{array}$ & - & 1 & 1 \\
\hline horizontal and diagonal lines and diagonal rows of tool punctates & 1 & - & 1 \\
\hline horizontal line and rectilinear zone with tool punctates & - & 2 & 2 \\
\hline $\begin{array}{l}\text { horizontal line, vertical panel with tool } \\
\text { punctates and vertical rows of punctates }\end{array}$ & - & 1 & 1 \\
\hline parallel lines and adjacent tool punctated zone & - & 10 & 10 \\
\hline parallel incised panel filled with tool punctates & - & 1 & 1 \\
\hline semi-circular and triangular zones filled with tool punctates & 1 & - & 1 \\
\hline straight line and adjacent circular punctated zone & - & 5 & 5 \\
\hline straight line and adjacent tool punctated zone & - & 35 & 35 \\
\hline straight line and adjacent tool punctated row & - & 1 & 1 \\
\hline straight line and circular punctated zone on either side of the line & - & 3 & 3 \\
\hline straight line and tool punctated zone on either side of the line & - & 8 & 8 \\
\hline triangles filled with circular punctates & - & 1 & 1 \\
\hline triangles filled with tool punctations & 11 & 9 & 20 \\
\hline $\begin{array}{l}\text { triangles filled with tool punctations and } \\
\text { horizontal lines with tool punctated row } \\
\text { between lines or underneath lines }\end{array}$ & 1 & - & 1 \\
\hline $\begin{array}{l}\text { vertical incised panels either plain or filled } \\
\text { with vertical tool punctated rows }\end{array}$ & 2 & - & 2 \\
\hline vertical incised panel filled with tool punctates & - & 1 & 1 \\
\hline Totals & 24 & 100 & 124 \\
\hline
\end{tabular}




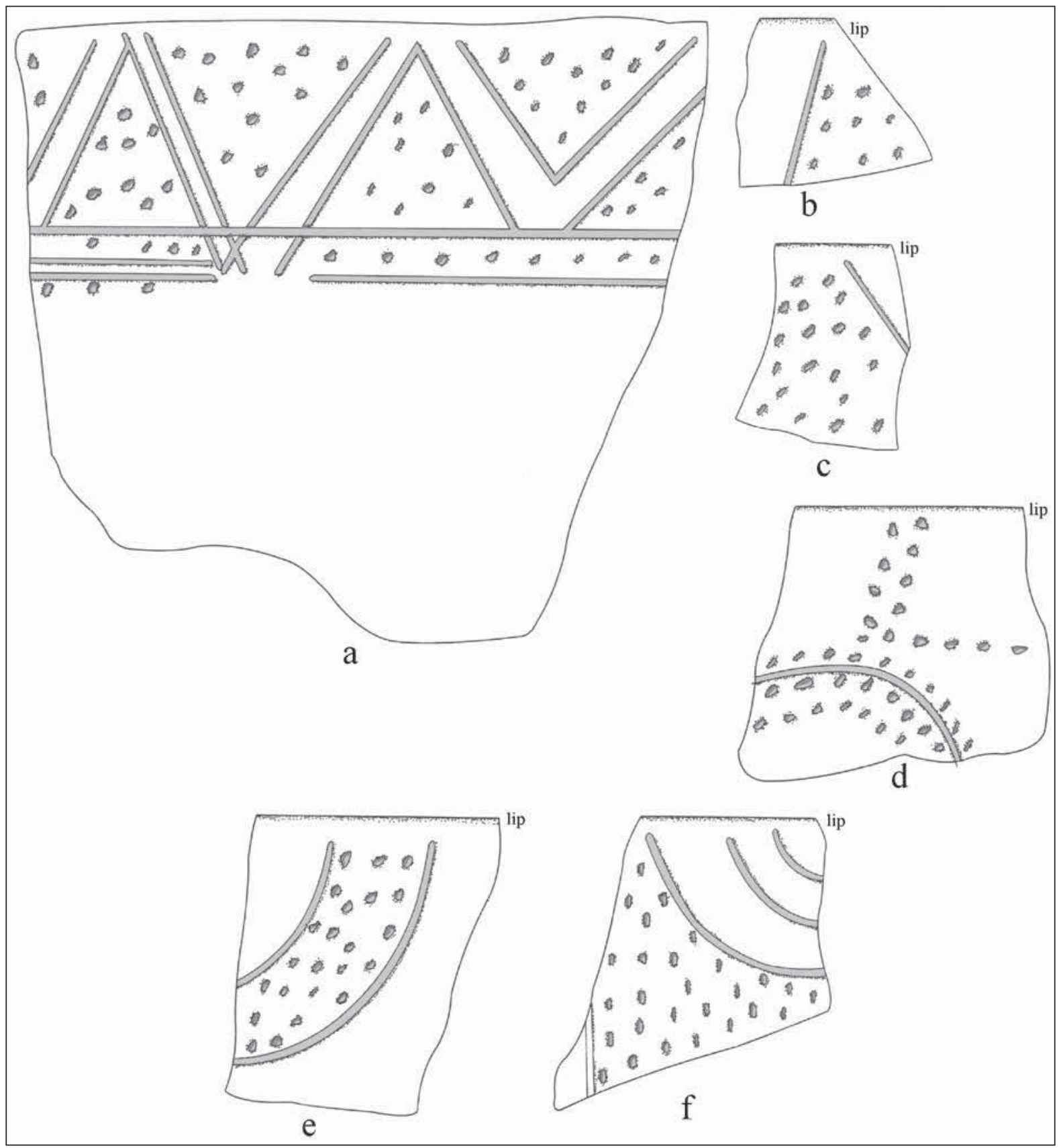

Figure 10a-f. Selected incised-punctated rim sherds from the Blount site.

There are also diagonal incised panels on rim sherds that are filled with punctations (see Figure 10h-i), along with a rim with semi-circular and triangular zones filled with tool punctates (see Figure 10j). Another distinctive incised-punctated decorative element on the rim sherds from the Blount site is vertical incised panels either plain or filled with vertical tool punctated rows; this is categorized below as Pineland Punctated-Incised, var. Blount.

Body sherds have similar incised-punctated decorative elements, ranging from diagonal panels to incised circular zones filled with punctations (Figure 11a-c). Others have curvilinear and semi-circular incised zones or panels filled with punctations (Figure 11d-f). One body sherd has parallel incised panels filled with linear tool punctations (Figure 11g). 


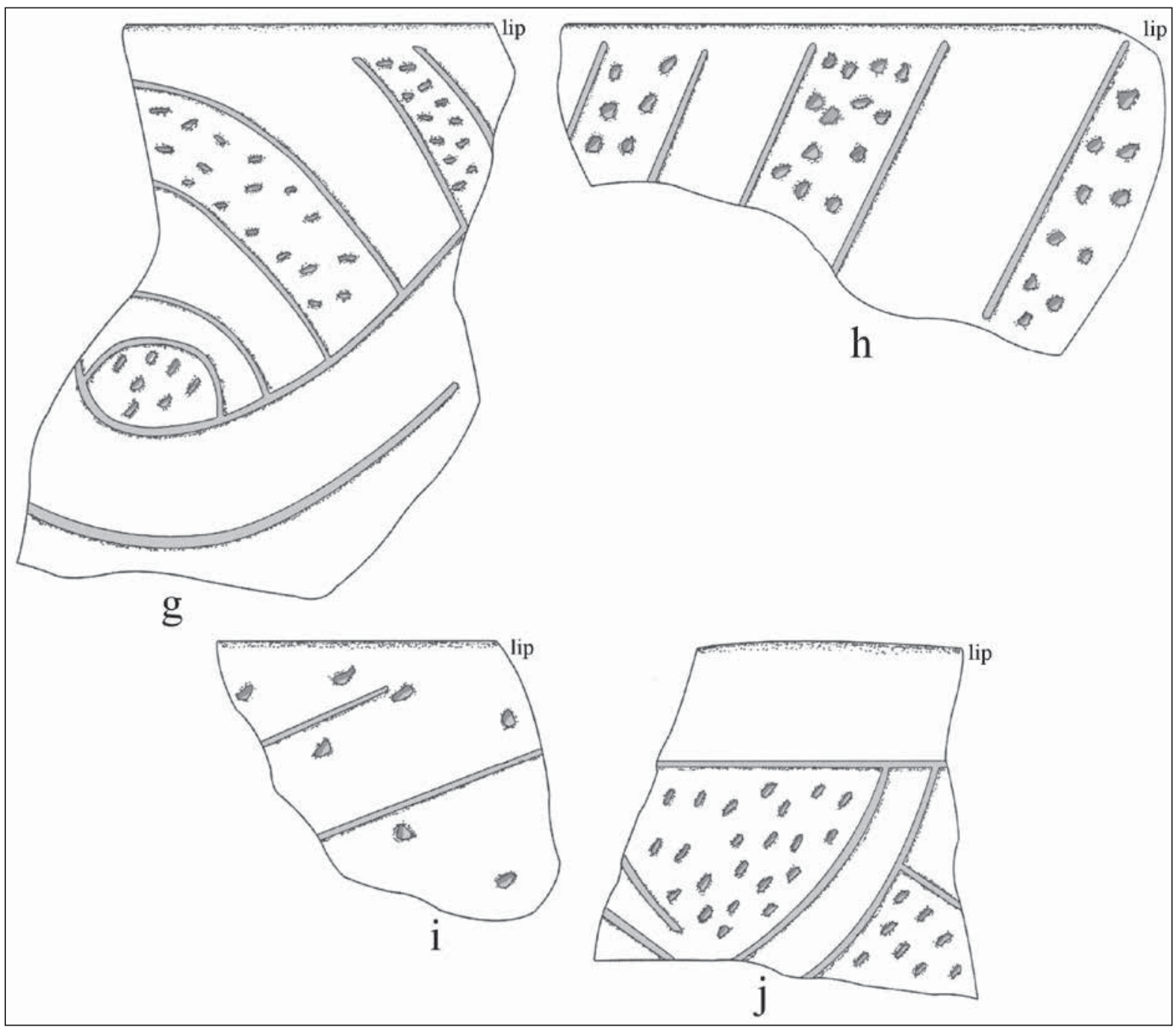

Figure $10 \mathrm{~g}-\mathrm{j}$. Selected incised-punctated rim sherds from the Blount site.

\section{SUMMARY AND CONCLUSIONS}

Incised-punctated sherds and vessels are among the most distinctive of the utility ware ceramics found on ancestral Caddo sites at Lake Sam Rayburn, although they are not the most common utility ware; overall, sherds with brushed decorative elements are the most common utility wares. Jelks (1965) had included the incised-punctated sherds from the Lake Sam Rayburn sites in his Pineland Punctated-Incised type, while the brushed sherds comprise his Broaddus Brushed type.

Our analysis of the incised-punctated rim and body sherds in the Lake Sam Rayburn site collections held by the Texas Archeological Research Laboratory at The University of Texas at Austin indicates that there is a diverse set of incised-punctated decorative elements represented in the various assemblages. They can be sorted into seven analytical categories (not including un-oriented body sherds with parallel or straight incised lines and adjacent punctated zones or rows) based on the character of the incised zones or panels that are filled with punctations: circular, curvilinear, diagonal, horizontal, semi-circular, triangular, and vertical. The most common decorative elements are triangular incised zones filled with punctations (37 percent of the rim sherds), as well as horizontal zones/panels (22 percent of the rim sherds), and diagonal zones or panels (16.7 percent of the rim sherds). Do these different incised-punctated decorative elements have temporal significance? 


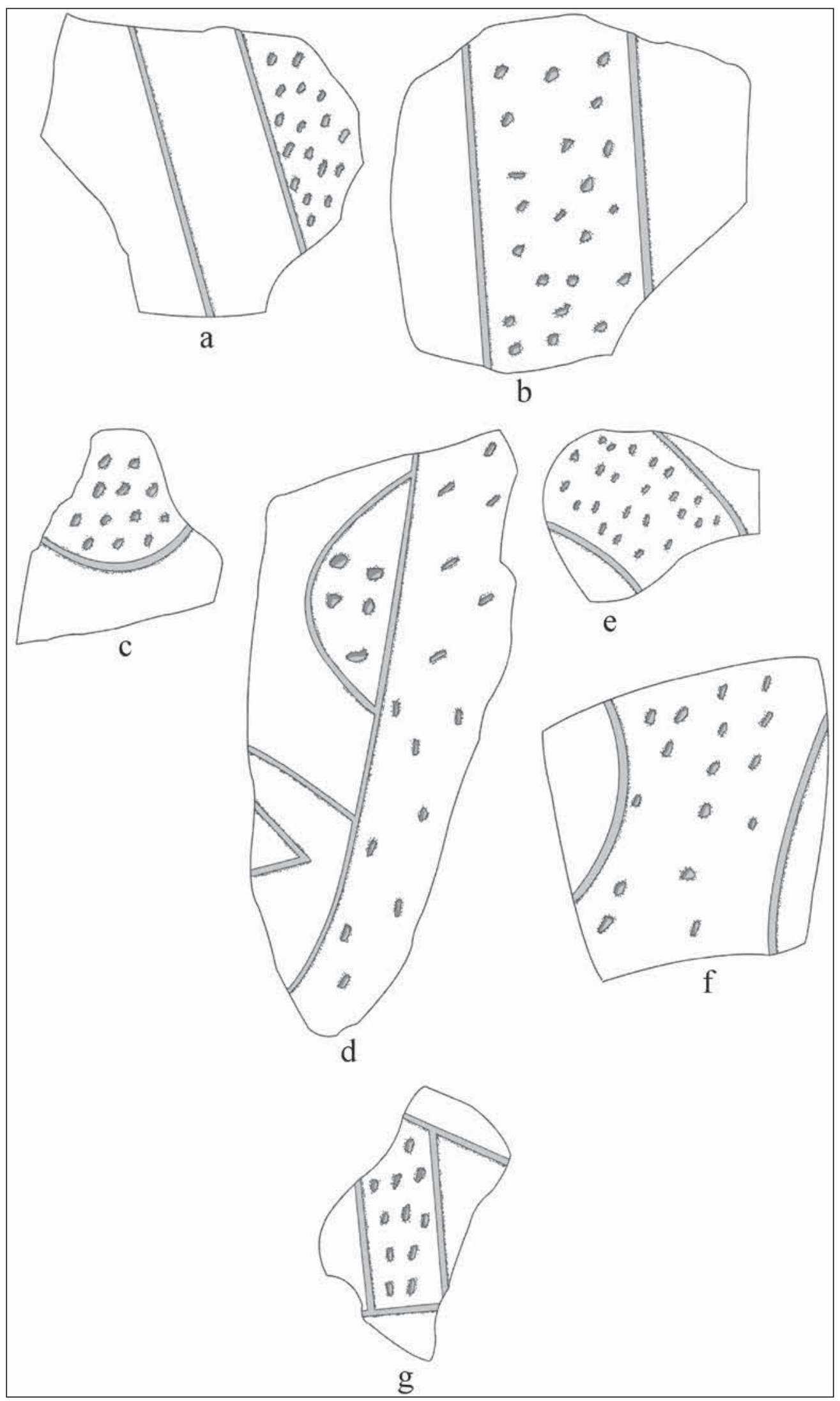

Figure 11. Selected incised-punctated body sherds from the Blount site. 
Sherds from brushed utility ware vessels, particularly jars, are a distinctive characteristic of both Middle, Late, and Historic Caddo sites in much of East Texas. It also appears to be the case that the relative proportions of brushed utility wares increase through time from its initial appearance around ca. A.D. 1200 in those areas where brushed vessels were made and used, such that sherds with brushing marks may comprise as much as 90 percent of all the decorated sherds in some post-A.D. 1400 East Texas ceramic assemblages. Brushed sherds are present in each of the Lake Sam Rayburn sites (see Table 1), and it is likely the case that each of the sites were occupied by Caddo peoples after ca. A.D. 1200. The proportions of brushed sherds, as well as plain/brushed sherd ratios (see Middlebrook 1994), in the assemblages allow them to be sorted into three groups that are considered to have temporal significance:

1. Youngest assemblages, post-dating ca. A.D. 1400/1450: Wylie Price (61 percent of the utility ware sherds have brushed decorative elements); Brink Powell (61 percent); Etoile (58 percent), and Walter Bell (50 percent);

2. Middle group of assemblages, pre-dating ca. A.D. 1400/1450, perhaps dating after ca. A.D. 1300: Blount (36 percent of the utility ware sherds have brushed decorative elements); Sawmill (32 percent) and McElroy (29 percent); and

3. Oldest assemblages, pre-dating ca. A.D. 1400/1450, perhaps dating from ca. A.D. 1200-1300: Print Bell (11 percent of the utility ware sherds have brushed decorative elements); and Sowell (19 percent).

These groups are employed to examine if there are differences in the decorative elements recognized in the incised-punctated sherds in the various Lake Sam Rayburn utility ware assemblages. The focus is on rim sherds from the Brink Powell, Walter Bell, Sawmill, Blount, and Print Bell sites.

As Table 10 indicates, there are differences in the incised-punctated decorative elements by proposed temporal groupings of the Lake Sam Rayburn assemblages. In the oldest assemblage, in what is now recently labeled the Blount phase (Tom Middlebrook, April 20, 2015 personal communication), incised-punctated rim sherds with horizontal zones/panels (Pineland Punctated-Incised, var. Print) and semi-circular zones (Pineland Punctated-Incised, var. Bell) are predominant. The later components in the Blount phase - the Sawmill and Blount sites - are distinctive in having incised-punctated sherds with circular zones and vertical panels (Pineland Punctated-Incised, var. Blount), as well as incised-punctated sherds with circular incised zones filled with punctations (Table 10); fingernail punctated elements are common in the Sawmill site assemblage (see Table 7). Sherds with curvilinear incised zones are also most common in this second grouping (Pineland Punctated-Incised, var. Sawmill).

Table 10. Incised-punctated rim decorative elements by proposed temporal groupings.

\begin{tabular}{llll}
\hline $\begin{array}{l}\text { Principal decorative } \\
\text { element }\end{array}$ & $\begin{array}{l}\text { Powell/ } \\
\text { Walter Bell }\end{array}$ & $\begin{array}{l}\text { Sawmill/ } \\
\text { Blount }\end{array}$ & Print Bell \\
\hline circular zones & - & $\underline{\mathbf{3 . 2}}$ & - \\
curvilinear zones & 8.2 & $\underline{\mathbf{1 2 . 9}}$ & - \\
diagonal zones/panels & 18.2 & 16.1 & 16.7 \\
horizontal zones/panels & $18.2^{*}$ & 16.1 & $\underline{\mathbf{4 1 . 7}}$ \\
triangle zones & $\underline{\mathbf{5 4 . 5}}$ & 38.7 & 16.7 \\
semi-circular zones & - & 6.4 & $\underline{\mathbf{2 5 . 0}}$ \\
vertical panels & - & $\underline{\mathbf{6 . 4}}$ & - \\
\hline Totals & 11 & 31 & 12 \\
\hline
\end{tabular}

*percentage

Bold and underlined values indicate the highest proportions amongst the three groups 
Rim sherds with incised triangles filled with punctations are present in all three site groupings, but are particularly common in the latest site assemblages, of the Late Caddo Bell phase (Tom Middlebrook, April 20, 2015 personal communication). They account for more than 54 percent of the rim sherds (see Table 10). These rims are classified as Pineland Punctated-Incised, var. Powell.

In conclusion, the incised-punctated sherds from utility ware vessels at ancestral Caddo sites in the Angelina River basin in East Texas have distinctive stylistic characteristics. These characteristics - in particular the form of the incised zones or panels that are filled with punctations (primarily tool punctates, but circular and fingernail punctates are also noted in some decorative elements) - appear to change continuously through time, from ca. A.D. 1200 to after ca. A.D. 1400/1450. The earliest ceramic assemblage is dominated by incised-punctated sherds with either horizontal zones/panels and semi-circular zones, while the post-A.D. 1400/1450 incised-punctated sherds have primarily incised triangle zones filled with punctations.

\section{ACKNOWLEDGMENTS}

Lance Trask prepared the figures in this article. Thanks to the staff at the Texas Archeological Research Laboratory at The University of Texas at Austin for access to the collections from the Lake Sam Rayburn sites.

\section{REFERENCES CITED}

Jelks, E. B.

1965 The Archeology of McGee Bend Reservoir, Texas. Ph.D. dissertation, Department of Anthropology, The University of Texas at Austin.

Middlebrook, T.

1994 An Update of Archaeological Investigations at the Tyson Site (41SY92). Journal of Northeast Texas Archaeology 3:1-36.

Perttula, T. K.

2015 Caddo Sites on Patroon, Palo Gaucho, and Housen Bayous in Sabine County in the Sabine River Basin of East Texas. Journal of Northeast Texas Archaeology 54:63-91.

Perttula, T. K. and M. Walters

2015 Woodland and Caddo Period Sites at Toledo Bend Reservoir, Northwest Louisiana and East Texas. Journal of Northeast Texas Archaeology 56:19-24.

2016 Caddo Ceramic Vessels from Lake Sam Rayburn Sites. Journal of Northeast Texas Archaeology 61:65-89.

Stokes, J. and J. Woodring

1981 Native-Made Artifacts of Clay. In Archeological Investigations at the George C. Davis Site, Cherokee County, Texas: Summers of 1979 and 1980, edited by D. A. Story, pp. 135-238. Occasional Papers No. 1. Texas Archeological Research Laboratory, The University of Texas at Austin.

Suhm, D. A. and E. B. Jelks (editors)

1962 Handbook of Texas Archeology: Type Descriptions. Special Publication No. 1, Texas Archeological Society, and Bulletin No. 4, Texas Memorial Museum, Austin. Reprinted in 2009, Gustav's Library, Davenport, Iowa. 